\title{
Identification and characterization of karyotype in Passiflora hybrids using FISH and GISH
}

\author{
Gonçalo Santos Silva ${ }^{1}$, Margarete Magalhães Souza ${ }^{1 *}$, Cláusio Antônio Ferreira de Melo', \\ Juan Domingo Urdampilleta ${ }^{2}$ and Eliana Regina Forni-Martins ${ }^{3}$
}

\begin{abstract}
Background: A great interest exists in the production of hybrid plants of the genus Passiflora given the beauty and exotic features of its flowers which have ornamental value. Hybrid paternity confirmation is therefore important for assuring germplasm origin, and is typically carried out by molecular marker segregation. The aim of this study was to karyotypically characterize the chromosome heritance patterns of the progeny resultant from a cross of $P$. gardneri and P. gibertii using classical cytogenetics, chromosome banding, and molecular cytogenetics.

Results: All analyzed genotypes showed the same diploid chromosome number as the genitor species: $2 n=18$. Classical and $\mathrm{CMA}_{3}$ and DAPI staining allowed for chromosome counting and satellite identification (secondary constrictions). Fluorescence in situ hybridization (FISH) and genomic in situ hybridization (GISH) were used to characterize subgenomes by either identifying rDNA-specific genome patterns or parental genomes, respectively.

Conclusions: The heritance of chromosomal markers presenting rDNA sites from each parent for genome identification confirmed that all obtained plants were hybrids. These results will improve breeding programs involving the species of this genus. Apart from confirming hybridization, GISH allowed the visualization of recombination between the homeologous chromosome and the introgression of sequences of interest.
\end{abstract}

Keywords: $\mathrm{CMA}_{3}$ and DAPI banding, FISH, GISH, Interspecific hybrids, Passion flowers

\section{Background}

The genus Passiflora L., comprising more than 525 species, is the largest within the family Passifloraceae A.L. de Jussieu ex Kunth [1]. Brazil is an important center of diversity with 137 species [2]. Certain species of the genus Passiflora have attracted a large economic interest for food purposes, highlighted by the sour passion fruit (P. edulis $\mathrm{f}$. flavicarpa O. Deg.) [3], as well as for medicinal purposes [4] and ornamental use [5, 6]. The ornamental plant market has expressed great interest in interspecific hybrids in order to facilitate the production of plants with unique characteristics [5]. Most of the hybrids described yield beautiful flowers and exotic foliage varying in color and shape, an essential feature for ornamentation [7].

\footnotetext{
* Correspondence: souzamagg@yahoo.com.br

'Departamento de Ciências Biológicas, Universidade Estadual de Santa Cruz (UESC), Ilhéus, BA, Brazil

Full list of author information is available at the end of the article
}

Passiflora species are widely available in the ornamental plant markets of Europe, Japan, and the USA [2]. However, the ornamental potential of Passiflora species remains practically unexplored in Brazil, although the location of Brazil in the tropical zone provides favorable climatic conditions for its cultivation [6]. Passiflora breeding programs with ornamental intentions have recently gained prominence in Brazil, attempting to produce hybrids possessing unique characteristics, considering the edaphoclimatic conditions of the country [8].

The production of Passiflora hybrids for ornamental purposes started a long time ago, yet the genomic and cytogenetic characterization of the generated hybrids is not well explored. Studies verifying the genetic and genomic compatibility of these hybrids and what factors can affect their fertility are therefore necessary. Hybrid identification can be carried out using different techniques, ranging from simple and low-cost options using morphological characteristics

(c) The Author(s). 2018 Open Access This article is distributed under the terms of the Creative Commons Attribution 4.0 International License (http://creativecommons.org/licenses/by/4.0/), which permits unrestricted use, distribution, and reproduction in any medium, provided you give appropriate credit to the original author(s) and the source, provide a link to the Creative Commons license, and indicate if changes were made. The Creative Commons Public Domain Dedication waiver (http://creativecommons.org/publicdomain/zero/1.0/) applies to the data made available in this article, unless otherwise stated. 
[9] to protocols employing molecular markers such as Random Amplified Polymorphic DNA (RAPD), Simple Sequence Repeat (SSR), Amplified Fragment Length Polymorphism (AFLP), and expressed sequence tags (ESTs) [10]. The use of cytogenetic data also offers significant results in hybrid analysis, with conventional and molecular cytogenetics providing a variety of chromosomal characteristics [11]. Chromosomal markers are a useful tool for identifying hybrids and allow the observation of the stability of hybrids produced in breeding programs $[12,13]$.

Molecular cytogenetic techniques, such as fluorescence in situ hybridization (FISH), are useful for paternity confirmation in hybrids. In particular, specific chromosomes with different marks may be useful, such as the $45 \mathrm{~S}$ and $5 \mathrm{~S}$ ribosomal DNA probes (rDNA). Chromosomes presenting rDNA sites can be used as markers to identify the genomes of the hybrid genitor species [14]. In addition, marker chromosomes can aid the observation of karyotype stability during the production of neo-hybrids, improving breeding programs. Another technique which has been widely used for hybrid identification is genomic in situ hybridization (GISH), which involves the use of the total genomic DNA from one species as a probe [15], enabling the observation of the respective genomes of each species present in the hybrid, as well as the observation of whether chromosomal recombination is occurring in different generations of hybrid progeny $[16,17]$.

Passiflora hybridization can be confirmed by morphological and molecular markers using techniques such as RAPD [18, 19] and SSR [8], which are more reliable methodologies for paternity confirmation in passion fruit hybrids. Recently, GISH has been used to confirm hybridization within the genus [20] and to analyze chromosomal recombination in $\mathrm{RC}_{1}$ hybrids [21]. The use of FISH for checking hybridization in Passiflora species has not been reported. However, this technique has been employed within the genus, specifically, using $45 \mathrm{~S}$ and $5 \mathrm{~S}$ rDNA probes to characterize some species [22] and somatic hybrids [23].

The aim of this study was to karyotypically characterize the hybrids and their genitors (Passiflora gardneri vs. Passiflora gibertii) obtained in an ornamental plant breeding program using classical cytogenetics and staining with specific-base fluorochromes. This study also sought to confirm paternity using in situ hybridization, using GISH and FISH to eliminate the hypothesis of self-fertilization and to evaluate genome cytogenetic stability based on chromosome markers.

\section{Methods}

\section{Plant material}

The species Passiflora gardneri Mast. (female parent) and Passiflora gibertii NE Brown (male parent) were kept in the Active Germplasm Bank (BAG-Passifloras), located on the campus of the State University of Santa
Cruz (UESC) in the city of Ilhéus, Bahia (longitude 39 10 “W, latitude 1439 ”-S, altitude $78 \mathrm{~m}$ ). Both species were obtained from the Brazilian Agricultural Research Corporation (Embrapa Cerrados), Brasilia, Brazil. The genitor species were selected based on leaf and flower characteristics. P. gardneri presents characteristics, including the structure of its flowers as well as an abundant flowering period running from September to March, which elicits the interest of the ornamental plant market. Likewise, $P$. gibertii is attractive because it presents early growth and flowering, and produces up to 30 flowers per day under normal conditions. Additionally, $P$. gibertii presents resistance to premature death and fusariosis, with has caused great damage to Brazilian passion fruit culture. Finally, $P$. gibertii and $P$. gardneri belong to the same infrageneric level (subgenus Passiflora, section Granadillastrum). The interspecific crossings between P. gardneri vs. P. gibertii were performed in a greenhouse with temperature ranging from 25 to $30{ }^{\circ} \mathrm{C}$ and a relative air humidity of $70-90 \%$. Pre-anthesis flower buds were protected with white paper bags the day prior to artificial pollination. Fruits resulting from hybridization were protected with nylon nets. After the fruits were fully mature, the seeds were propagated. Twenty-five hybrids germinated and were kept in a greenhouse. The hybrids that presented normal growth and flowering, as well as a wide segregation of colors, shapes, and sizes in their floral parts were selected. Eight $\mathrm{F}_{1}$ interspecific hybrids (HD15101, HD15-104, HD15-106, HD15-107, HD15-108, HD15109, HD15-110, HD15-111) were analyzed.

\section{Slide preparation}

Root tips of approximately $1 \mathrm{~cm}$ in length were collected, pre-treated with 0.002 M 8-hydroxyquinoline (8-HQ; Merck) for $1 \mathrm{~h}$ at room temperature (RT) and a further $21 \mathrm{~h}$ at $8^{\circ} \mathrm{C}$ to $10^{\circ} \mathrm{C}$. After being washed twice in distilled water and fixed in Carnoy (anhydrous ethanol (Merck): glacial acetic acid (Merck) [3:1], v/v; [24]) for $3 \mathrm{~h}$ at RT, the samples were stored at $-20{ }^{\circ} \mathrm{C}$ for at least $24 \mathrm{~h}$. For slide preparation, root apices were washed twice in distilled water and incubated in a humidity chamber at $37{ }^{\circ} \mathrm{C}$ with $50 \mu \mathrm{l}$ of $2 \%$ cellulase enzyme solution (Sigma) and $20 \%$ pectinase $(w / v)$ (Sigma) for $80 \mathrm{~min}$. The enzymes were then removed using a micropipette, and the root samples were washed again in distilled water and then added $10 \mu \mathrm{l}$ of $45 \%$ acetic acid (Merck). Roots were then macerated using needles under a stereomicroscope, covered with a cover slip, pressed firmly between filter paper, frozen in liquid nitrogen for approximately $6 \mathrm{~min}$ to remove the cover slip, and finally air dried. Slide preparations featuring good presentation of cells in metaphase were kept at $-20{ }^{\circ} \mathrm{C}$ until the application of cytogenetic techniques. 
Conventional cytogenetic staining for establishing chromosome count was performed following the protocol of Guerra and Souza [25] with modifications consisting of the use of $2 \%$ Giemsa solution (Merck) for 20-30 min, followed by briefly rinsing the slides in distilled water and air drying. After staining, the slides were mounted with Neo-Mount medium (Merck) and then coverslipped.

\section{$\mathrm{CMA}_{3} / \mathrm{DA} / \mathrm{DAPI}$ chromosome banding}

In order to locate heterochromatin rich in GC and AT, slides were aged for 3 days prior to staining. We have used the fluorochromes Chromomycin $\mathrm{A}_{3}\left(\mathrm{CMA}_{3} ;\right.$ Sigma) and 4'-6-Diamidino-2-phenylindole (DAPI; Sigma) to stain GC and AT base pairs, respectively. A combination of the non-fluorescent antibiotic Distamycin (DA; Sigma) and the fluorochrome DAPI (DA/DAPI) favors differential staining by highlighting loci predominantly composed of AT bases. Coloration with $\mathrm{CMA}_{3} / \mathrm{DA} / \mathrm{DAPI}$ was performed following the protocol used by Guerra and Souza [25], with an alteration in the $\mathrm{CMA}_{3}$ concentration used [26]. Slides were treated with $15 \mu \mathrm{l} \mathrm{CMA}{ }_{3}(0.25 \mathrm{mg} / \mathrm{ml})$ for $1 \mathrm{~h}$, then washed with distilled water and dried. Subsequently, $15 \mu \mathrm{l}$ Distamycin A $(0.1 \mathrm{mg} / \mathrm{ml})$ was applied for $30 \mathrm{~min}$, following which slides were washed with distilled water and dried, then treated with $15 \mu$ DAPI $(2 \mathrm{mg} / \mathrm{ml})$ for $30 \mathrm{~min}$. Finally, slides were washed with distilled water, dried, mounted using $15 \mu \mathrm{l}$ of assembly medium glycerol (Sigma)/Mcllvaine $(1: 1 \mathrm{v} / \mathrm{v})$, and coverslipped (20x $20 \mathrm{~mm}$ ). Slides were stored a darkened chamber for 3 days before analysis.

\section{In situ hybridization probes}

DNA from both parent species were extracted using the protocol of Doyle and Doyle [27] for the production of in situ hybridization probes. For GISH, P. gibertii total genomic DNA was labeled with biotin-16-dUTP (Roche Diagnostics) via nick translation, and P. gardneri total genomic DNA was used as blocking DNA. To prepare blocking DNA, genomic DNA was cleaved with a sonicator (Qsonica Q125) in order to obtain bands preferably between 100 and $800 \mathrm{bp}$. Sonication resulted in the generation of fragments predominantly between 200 and $1000 \mathrm{bp}$. In order to break the blocking DNA, about $20 \mu \mathrm{g}$ of genomic DNA in a final volume of $200 \mu \mathrm{l}$ was cleaved using sonicator (amplitude 40\%, alternating pulses of $2 \mathrm{~s}$ on and $2 \mathrm{~s}$ off, total duration $5 \mathrm{~min}$ ) [28]. The sizes of the cleaved fragments was checked using electrophoresis in agarose gel (Pronadisa) 2\% using a 100 bp ladder marker as a reference (New England Biolabs). Purification of the cleaved genomic DNA was accomplished through the precipitation of nucleic acids by adding $2 \%$ of the final sodium acetate volume (Sigma) to $3 \mathrm{M}$ plus $200 \%$ of the final volume of anhydrous ethanol (Merck).The mixture was stored at $-20{ }^{\circ} \mathrm{C}$ overnight and then centrifuged (Novatecnica $805 \mathrm{NT}$ ) for $10 \mathrm{~min}$ at $14,000 \mathrm{rpm}$ at $20{ }^{\circ} \mathrm{C}$ to isolate the pellet and eliminate the supernatant. The pellet was dried at $\mathrm{RT}$ for at least $1 \mathrm{~h}$ before being resuspended with ultrapure water to generate a final DNA concentration of $1.1 \mu \mathrm{g} / \mu \mathrm{L}$.

For FISH, pTa71 [29] clones (a donation from the Biosystematics Laboratory, Institute of Biology, State University of Campinas, SP, Brazil) were used to obtain probes for $45 \mathrm{~S}$ rDNA sites, which were labeled with biotin-16-dUTP (Roche Diagnostics). Probes for 5S rDNA sites were obtained via polymerase chain reaction (PCR) using specific primers (5'-GTGCGATCATACCA GRYTAATGCACCGG-3' and 5'-GAGGTGCAACACG AGGACTTCCCAGGAGG -3') [22] and labeled with digoxigenin-11-dUTP (Roche Diagnostics). The probes were labeled using nick translation, with a final DNA concentration of $1 \mu \mathrm{g}$, following the protocol proposed by the manufacturer.

The 45S and 5S rDNA probes were used for the identification of marker chromosomes, allowing for karyotype characterization and hybrid status verification.

\section{GISH and FISH}

Slides for FISH were treated in accordance with the protocol described by Schwarzacher and Heslop-Harrison [30] and Souza et al. [31] with modifications [20]. Slides with cytological preparations were dried at $37^{\circ} \mathrm{C}$ for at least $1 \mathrm{~h}$. Following this, slides were treated with $50 \mu \mathrm{l}$ of a solution containing $1 \mathrm{mg} / \mathrm{ml}$ RNase (Sigma) in $2 \times$ SSC (salt, sodium citrate) buffer $(0.3 \mathrm{M}$ sodium chloride [Sigma], 0.03 M sodium citrate [Sigma]) and incubated in a humidified chamber $1 \mathrm{~h}$ at $37^{\circ} \mathrm{C}$. The slides were the immersed in $2 \times$ SSC at RT twice for 5 min each, and then incubated with $50 \mu \mathrm{l} 10 \mathrm{mM}$ hydrochloric acid $(\mathrm{HCl}$; Vetec) for $5 \mathrm{~min}$. Following this, $\mathrm{HCl}$ was removed and replaced with $50 \mu \mathrm{l}$ of pepsin (Sigma) $[10 \mathrm{mg}$ pepsin $/ \mathrm{ml}$, $10 \mathrm{mM} \mathrm{HCl}(1: 100 \mathrm{v} / \mathrm{v})]$ and slides were incubated in a humidified chamber for $20 \mathrm{~min}$ at $37{ }^{\circ} \mathrm{C}$. The slides were then washed in $2 \times$ SSC at RT twice for 5 min each, immersed in $4 \%$ formaldehyde (Sigma) at $4 \%$ for $10 \mathrm{~min}$, and then rinsed again in $2 \times$ SSC twice for 5 min each. The wash steps were carried out using a shaker platform (Biomixer Mos-1) set at $120 \mathrm{rpm}$. Cytological preparations were dehydrated in 70\% and $95 \%$ ethanol for 5 min each. After drying the slides at RT for 30 min, slides were incubated with $15 \mu \mathrm{l}$ hybridization mix, consisting of $50 \%$ formamide (Sigma), 10\% dextran sulfate (Sigma), $2 \times$ SSC (Sigma), 0.13\% sodium dodecyl sulfate (SDS; Bioagency), and the probes. For GISH, we used 33 ng of probe and 3. $3 \mu \mathrm{g}$ of blocking DNA (100x), while for FISH, we used $50 \mathrm{ng}$ of either the $45 \mathrm{~S}$ or the $5 \mathrm{~S}$ probes. The hybridization mixture was heated at $75^{\circ} \mathrm{C}$ for $10 \mathrm{~min}$ in a 
thermocycler (Eppendorf Mastercycler) and immediately transferred to ice for a minimum incubation of $5 \mathrm{~min}$. Cytological preparations containing the hybridization mixture were denatured in a thermocycler (Techne TC-412) containing a slide adapter at $75{ }^{\circ} \mathrm{C}$ for $10 \mathrm{~min}$ and incubated overnight at $37{ }^{\circ} \mathrm{C}$ in a humidified chamber. After hybridization, slides were immersed in $2 \times$ SSC for $5 \mathrm{~min}$ at RT to facilitate coverslip removal, moved to a Dubnoff bath (Quimis Q226M2) set at $42{ }^{\circ} \mathrm{C}$, and immersed in $2 \times$ SSC for 5 min each, twice in $0.1 \times$ SSC for 5 min each, and twice again in $2 \times$ SSC for 5 min each. Finally, slides were dipped in $4 \times$ SSC containing $0.2 \%$ Tween 20 (Sigma) at RT for $5 \mathrm{~min}$ and then treated with $50 \mu \mathrm{l}$ of $5 \%$ bovine serum albumin (BSA; Sigma). Biotin-labeled probes were detected by incubating each slide with a $0.7 \mu \mathrm{l}$ avidinfluorescein isothiocyanate (FITC; Vector): $19.3 \mu \mathrm{l}$ 5\% BSA solution. Digoxigenin-labeled probes were detected by incubating each slide with a $0.7 \mu \mathrm{l}$ anti-digoxigeninrhodamine (Roche):19.3 $\mu$ l 5\% BSA solution. All slides containing antibodies were incubated in a humidified chamber for $1 \mathrm{~h}$ at $37^{\circ} \mathrm{C}$. Three washes of 5 min each with $4 \times$ SSC containing $0.2 \%$ Tween 20 were conducted to remove excess antibody. Finally, the slides were briefly immersed in $2 \times$ SSC and cytological preparations were mounted and counterstained with Vectashield ${ }^{\circ}$ Antifade Mounting Medium with DAPI (M-1200). The slides were stored at $8-10{ }^{\circ} \mathrm{C}$ until analysis.

\section{Chromosome Photodocumentation}

Metaphases following fluorochrome staining and in situ hybridization were photodocumented using an epifluorescent Olympus BX41 microscope equipped with a 5 MP Olympus DP25 digital camera and DP2-BSW software. $\mathrm{CMA}_{3}$ blocks were detected with a U-MWB filter (excitation 450-480 nm/dichroic cutoff $500 \mathrm{~nm} / \mathrm{emis}-$ sion $>515 \mathrm{~nm}$ ) and DAPI signal with a U-MWU filter (excitation 330-385 nm/dichroic cutoff $400 \mathrm{~nm} / \mathrm{emis}-$ sion $>420 \mathrm{~nm}$ ). Hybridizations detected using avidinFITC were visualized with a U-MWB filter (excitation $450-480 \mathrm{~nm} /$ dichroic cutoff $500 \mathrm{~nm} /$ emission $>515 \mathrm{~nm}$ ), while hybridizations detected using anti-digoxigeninrhodamine were visualized using a U-MWG filter (excitation 510-550 nm/dichroic cutoff $570 \mathrm{~nm} /$ emission $>590 \mathrm{~nm}$ ). DAPI counterstaining was detected with a U-MWU filter (excitation 330-385 nm/dichroic cutoff $400 \mathrm{~nm} /$ emission $>420 \mathrm{~nm}$ ). Slide images, karyograms, and FITC/DAPI overlays (for GISH) and FITC/ rhodamine/DAPI overlays (for 45S and 5S rDNA sites) were processed using Photoshop SC5.

\section{Results}

Conventional and Fluorochrome staining

Here, conventional staining was only able to aid in counting chromosome number $(2 n=18$; Additional file 1$)$.
$\mathrm{CMA}_{3} / \mathrm{DA} / \mathrm{DAPI}$ banding permitted the observation of satellites (secondary constriction) not visible with conventional staining. No DAPI ${ }^{+}$blocks were observed, and $\mathrm{CMA}_{3}{ }^{+} / \mathrm{DAPI}^{-}$blocks were restricted to satellites and secondary constrictions (Figs. 1, 2, and 5). The relationship between the $\mathrm{CMA}_{3}{ }^{+} / \mathrm{DAPI}^{-}$terminal blocks and satellites (secondary constriction) allowed for the confirmation of the number of satellites (secondary constriction) in both genitor species. Six $\mathrm{CMA}_{3}{ }^{+} / \mathrm{DAPI}^{-}$blocks were observed in the maternal parent (P. gardneri) and five in the paternal parent $(P$. gibertii). In the same individual analyzed, it was also observed a heteromorphic pair after conventional staining, with a single homolog carrying a satellite (secondary constriction) (Table 1). It was possible to observe $\mathrm{CMA}_{3}{ }^{+}$blocks, confirming the number of satellites (secondary constriction) in the eight analyzed hybrids (Table 1).

\section{Gish}

To check the relationship between the amount of blocking DNA and the probe, it is necessary to adjust blocking DNA concentrations to distinguish genomes. In this study, it was necessary to use 100× more blocking DNA than the probe to identify putative hybrids. No satisfactory results were obtained when using lower concentrations of blocking DNA, likely owing to strong cross-hybridization with the non-target genome.

GISH distinguished each parental chromosome set within the analyzed hybrids. In each plant, the nine chromosomes from the paternal parent were uniformly and wholly labeled with FITC, while the remaining nine chromosomes of maternal origin were unlabeled or presented a very low level of signal due to crosshybridization (DAPI counterstaining). Hybrids, like their parents, must be diploid individuals possessing $2 n=18$ chromosomes. GISH confirmed the hybrid character in all analyzed HD15 progeny plants (Fig. 3).

\section{$45 \mathrm{~S}$ and $5 \mathrm{~S}$ rDNA FISH}

The $45 \mathrm{~S}$ and $5 \mathrm{~S}$ rDNA sites were mapped in both parent plants and the eight interspecific hybrids (HD15) (Figs. 4 and 5). The number of $45 \mathrm{~S}$ and $5 \mathrm{~S}$ rDNA sites within each hybrid, as well as their parental origin, are shown in Table 1.

Parental karyotype identification was performed as follows: chromosome pairs were ordered by size in descending order, with P. gardneri chromosomes named 1A to $9 \mathrm{I}$ and $P$. gibertii chromosomes named 1a to $9 \mathrm{i}$. Hybrid genotype karyotype denomination was carried out by identifying parental chromosome markers using $45 \mathrm{~S}$ and $5 \mathrm{~S}$ rDNA hybridization sites, which were segregated in the hybrid progeny HD15. Chromosome pairs 1A, 4D, and 7G for P. gardneri presented 45S rDNA sites, while chromosome pairs $5 \mathrm{E}$ and 9I presented $5 \mathrm{~S}$ 

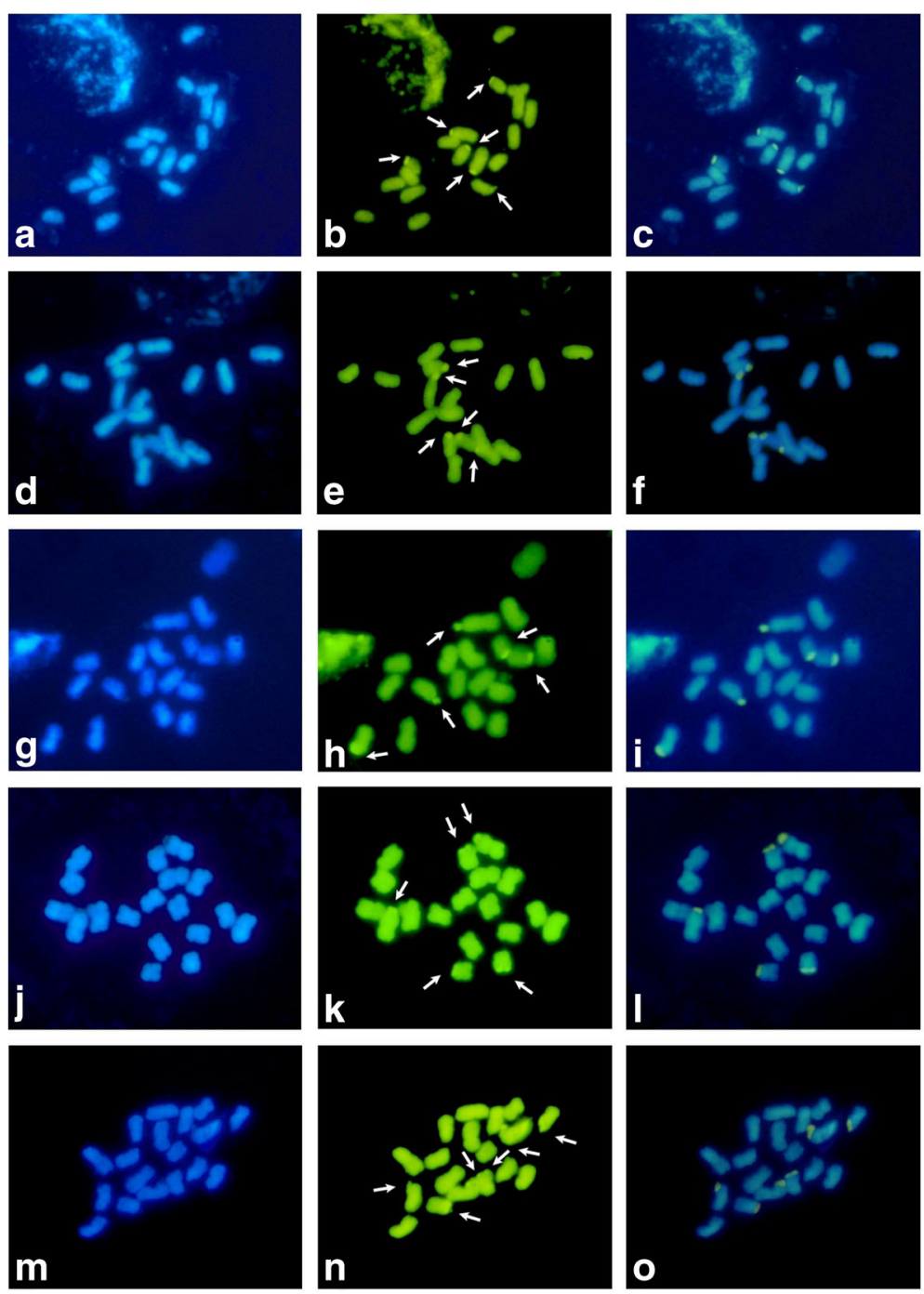

Fig. $1 \mathrm{CMA}_{3} / \mathrm{DA}$ DAPI banding of mitotic metaphase cells from parents and interspecific hybrids of Passiflora HD15 progeny. Staining with DAPI (a, $\mathbf{d}, \mathbf{g}, \mathbf{j}$, $\mathbf{m}), \mathrm{CMA}_{3}(\mathbf{b}, \mathbf{e}, \mathbf{h}, \mathbf{k}, \mathbf{n})$, and $\mathrm{CMA}_{3} / \mathrm{DAPI}$ merged $(\mathbf{c}, \mathbf{f}, \mathbf{i}, \mathbf{l}, \mathbf{o})$. a-c: P. gardneri Mast:; d-f: P. gibertii N. E. Brown; g-i: HD15-101; j-l: HD15-104; $\mathbf{m}-\mathbf{- o}$ : HD15-106. Arrows indicate $\mathrm{CMA}_{3}{ }^{+}$blocks. $\mathrm{Bar}=10 \mu \mathrm{m}$

rDNA sites. In $P$. gibertii, chromosome pairs $2 \mathrm{~b}, 7 \mathrm{~g}$, and 9i presented $45 \mathrm{~S}$ rDNA sites, while pair 5e presented $5 \mathrm{~S}$ rDNA sites (Fig. 4).

Hybrid karyotype analyses were based on the presence of marker chromosomes. The chromosomes with $45 \mathrm{~S}$ and $5 \mathrm{~S}$ rDNA sites maintained the same positions as in the genitor species. To facilitate identification, only marker chromosomes were numbered and named in the karyograms of the eight analyzed hybrids (Fig. 4c-j).

For the maternal genome (P. gardneri), chromosome $1 \mathrm{~A}$, which has a $45 \mathrm{~S}$ rDNA site on the long arm, was chosen as the primary marker identifying the presence of this genome in the hybrid because no hybridization signal from this chromosome was found in the paternal genome. Only the maternal genome was found to have $45 \mathrm{~S}$ rDNA sites in chromosomal long arms. Moreover, the fact that chromosome $1 \mathrm{~A}$ is longer than the others offers a uniqueness that prevents confusion. Chromosome $5 \mathrm{E}$, which is unique in having a $5 \mathrm{~S}$ rDNA site in the pericentromeric region of the long arm, was used as a secondary marker.

For the paternal genome ( $P$. gibertii), chromosome $5 \mathrm{e}$, which has a $5 \mathrm{~S}$ rDNA site in the terminal region of the long arm, was used as the primary marker, because this characteristic is exclusive for the paternal genome. Chromosome 9i, with a $45 \mathrm{~S}$ rDNA site in the terminal region of the short arm, was used as secondary marker, since it was the smallest chromosome present in the hybrids. The other chromosomes presenting rDNA sites could not be used as identifying markers in maternal and paternal genome due to site and size similarities. 

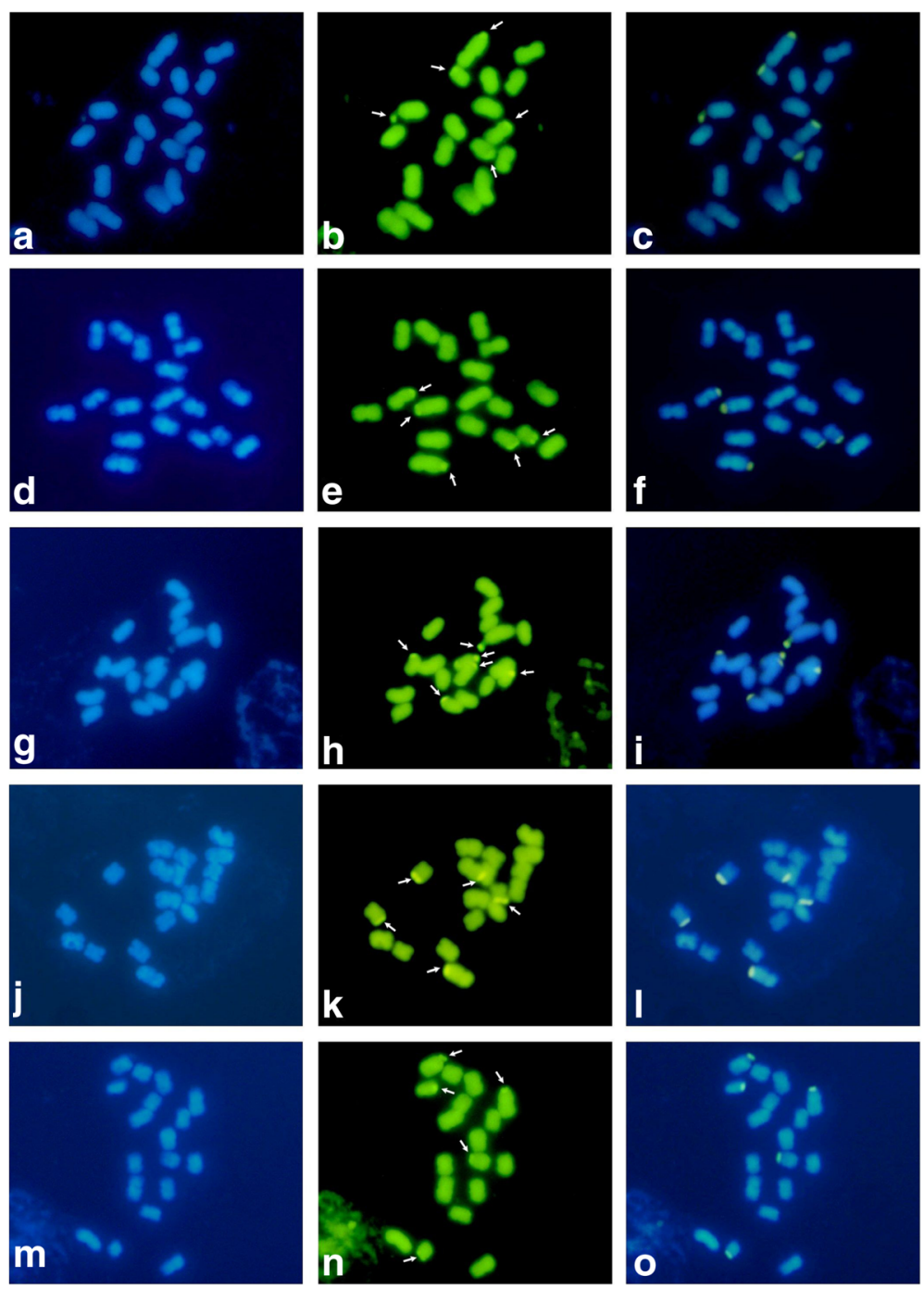

Fig. $2 \mathrm{CMA}_{3} / \mathrm{DA} / \mathrm{DAPI}$ banding of mitotic metaphase cells from interspecific hybrids of Passiflora HD15 progeny. Staining with DAPI (a, d, $\left.\mathbf{g}, \mathbf{j}, \mathbf{m}\right)$, $\mathrm{CMA}_{3}(\mathbf{b}, \mathbf{e}, \mathbf{h}, \mathbf{k}, \mathbf{n})$ and $\mathrm{CMA}_{3} / \mathrm{DAPI}$ merged (c, f, i, l, o). a-c: HD15-107; d-f: HD15-108; g-i: HD115-109; j-l: HD15-110; m-o: HD15-111. Arrows indicate $\mathrm{CMA}_{3}{ }^{+}$blocks. $\mathrm{Bar}=10 \mu \mathrm{m}$

Table 1 Karyotypic data based on $\mathrm{CMA}_{3} / \mathrm{DA} / \mathrm{DAPI}$ banding and FISH in Passiflora parents and interspecific hybrids

\begin{tabular}{|c|c|c|c|}
\hline Genotype & $\mathrm{CMA}_{3}{ }^{+}$ & $45 \mathrm{~S}$ rDNA & $5 S$ rDNA \\
\hline P. gardneri & 6 & 6 & 4 \\
\hline P. gibertii & 5 & 5 & 2 \\
\hline HD15-101 & 5 & $5(3 \mathrm{M} ; 2 \mathrm{P})$ & $3(2 \mathrm{M} ; 1 \mathrm{P})$ \\
\hline HD15-104 & 5 & $5(3 \mathrm{M} ; 2 \mathrm{P})$ & $3(2 \mathrm{M} ; 1 \mathrm{P})$ \\
\hline HD15-106 & 6 & $6(3 \mathrm{M} ; 3 \mathrm{P})$ & $3(2 \mathrm{M} ; 1 \mathrm{P})$ \\
\hline HD15-107 & 5 & $5(3 \mathrm{M} ; 2 \mathrm{P})$ & $3(2 \mathrm{M} ; 1 \mathrm{P})$ \\
\hline HD15-108 & 5 & $5(3 \mathrm{M} ; 2 \mathrm{P})$ & $3(2 \mathrm{M} ; 1 \mathrm{P})$ \\
\hline HD15-109 & 6 & $6(3 \mathrm{M} ; 3 \mathrm{P})$ & $3(2 \mathrm{M} ; 1 \mathrm{P})$ \\
\hline HD15-110 & 5 & $5(3 \mathrm{M} ; 2 \mathrm{P})$ & $3(2 \mathrm{M} ; 1 \mathrm{P})$ \\
\hline HD15-111 & 5 & $5(3 \mathrm{M} ; 2 \mathrm{P})$ & $3(2 M ; 1 P)$ \\
\hline
\end{tabular}

$\mathrm{CMA}_{3}{ }^{+}$number of $\mathrm{CMA}_{3}{ }^{+}$blocks, $45 \mathrm{~S}$ rDNA number of $45 \mathrm{~S}$ rDNA sites, 55 rDNA number of $5 S$ rDNA sites. $M$ site of maternal origin, $P$ site of paternal origin
The eight analyzed hybrids presented chromosomes with $45 \mathrm{~S}$ and $5 \mathrm{~S}$ rDNA sites in the characteristic positions aligning with each donor genome. In hybrids HD15-101, HD15-104, HD15-107, HD15-108, HD15110, and HD15-111, five 45S rDNA sites and three 5S rDNA sites were clearly observed, while six $45 \mathrm{~S}$ rDNA sites and three 5S rDNA sites were found in hybrids HD15-106 and HD15-109 (Table 1). For all analyzed plants, hybridization was confirmed through the presence of genome marker chromosomes.

\section{Discussion}

Interspecific hybridization has been conducted in Passiflora mainly for the production of new ornamental varieties with more attractive flowers and colors. The methods used for hybrid identification within the genus 


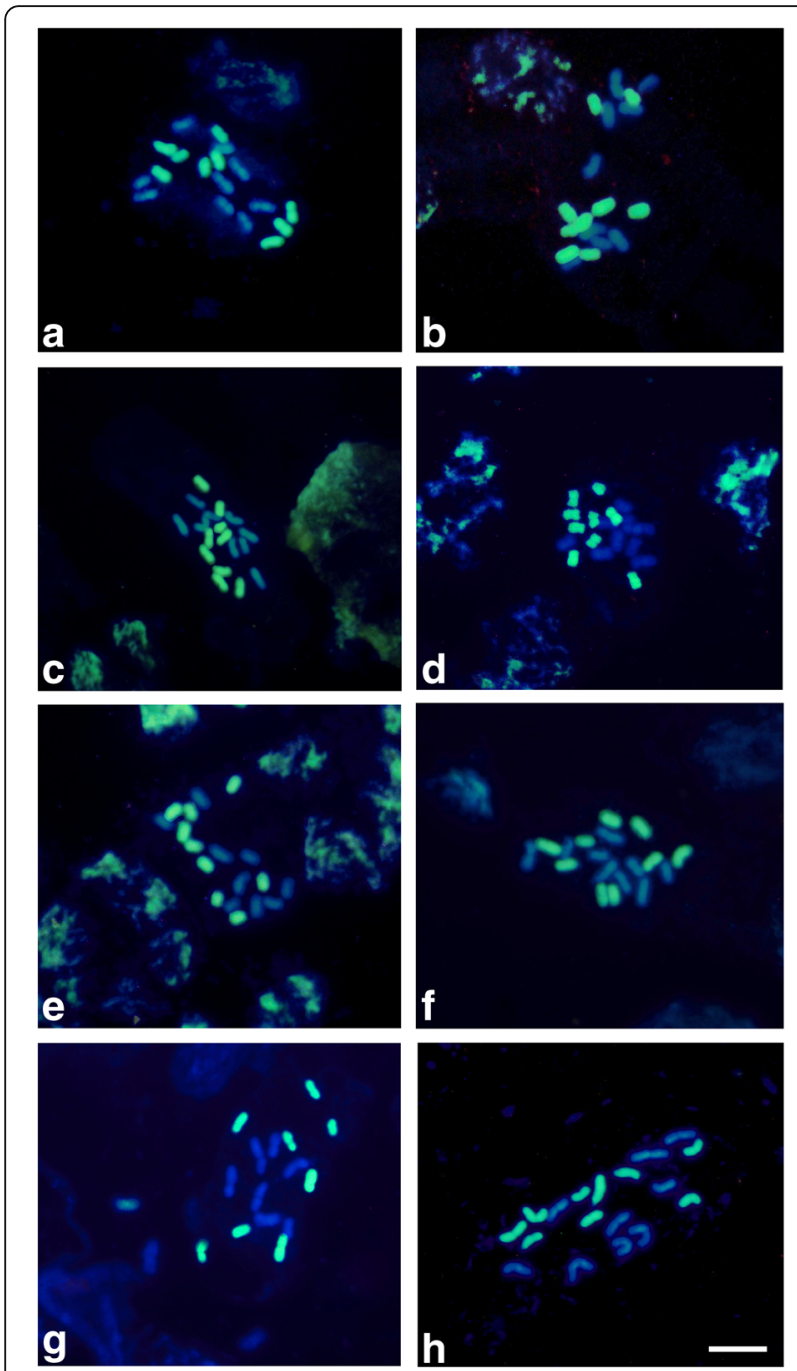

Fig. 3 Genomic in situ hybridization (GISH) analysis of mitotic metaphase cells from interspecific hybrids of Passiflora HD15 progeny. a HD15-101, (b) HD15-104, (c) HD15-106, (d) HD15-107, (e) HD15-108, (f) HD15-109, (g) HD15-110, (h) HD15-111. Bar = $10 \mu \mathrm{m}$

are mainly based on morphological characteristics [9], as well as the usage of RAPD $[18,19]$ and SSR [8] molecular markers. The application of classic, banding, and molecular cytogenetic techniques can be useful in hybrid identification, karyological characterization, chromosome stability analysis, and hybrid selection for breeding programs.

Karyotype analysis using only classical cytogenetic methods for hybrid identification was not possible due to the very similar morphologies between the chromosomes and difficulties in visualizing the satellites (secondary constrictions) using Giemsa staining alone. Unclear Giemsa staining results could lead to inaccurate hybrid identification. In a survey done in 2005, it was found that in most species of Passiflora, the utility of karyotype characterization was restricted to counting the
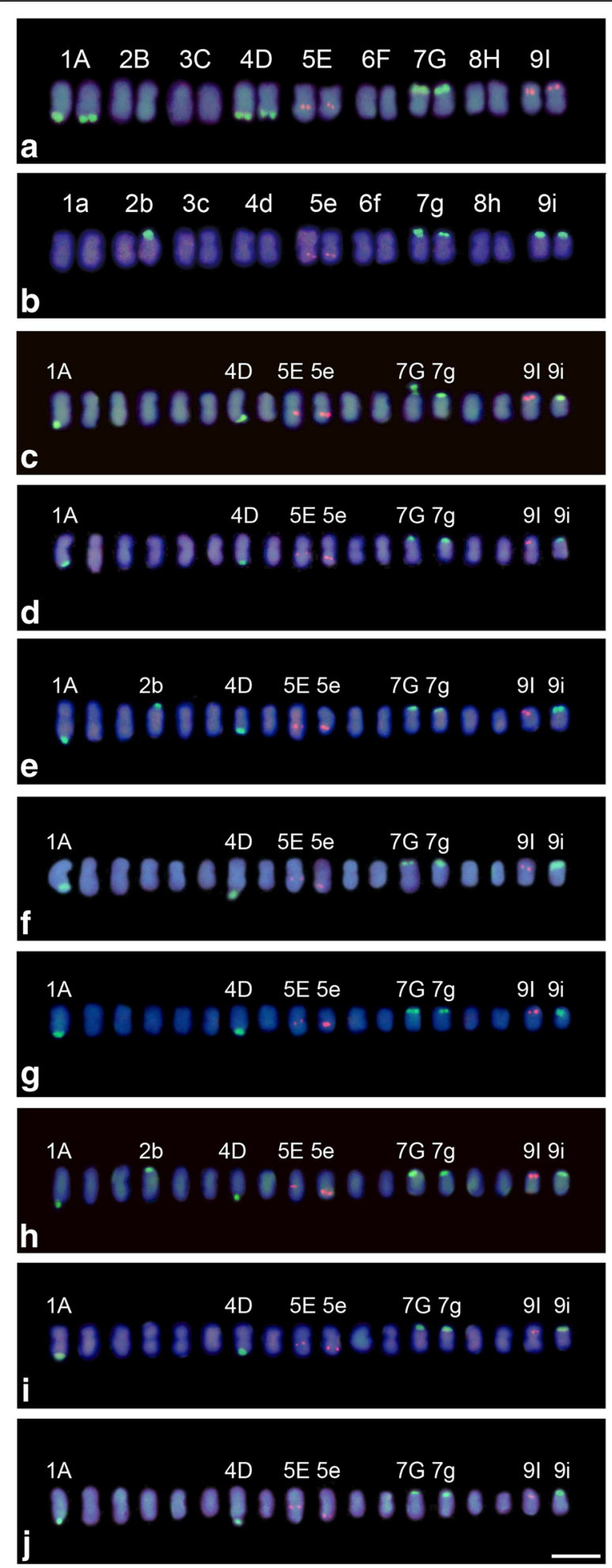

Fig. 4 Karyograms with $5 S$ and 45S rDNA probes for parents and interspecific hybrids of Passiflora HD15 progeny. a $P$. gardneri Mast., (b) $P$. gibertii N. E. Brown, (c) HD15-101, (d) HD15-104, (e) HD15-106, (f) HD15107, (g) HD15-108, (h) HD15-109, (i) HD15-110, (j) HD15-111. Letters and numbers for parent karyograms indicate chromosome pairs. Letters and numbers for hybrid karyograms indicate chromosomes with $45 \mathrm{~S}$ and $5 \mathrm{~S}$ rDNA sites. Bar $=10 \mu \mathrm{m}$ 

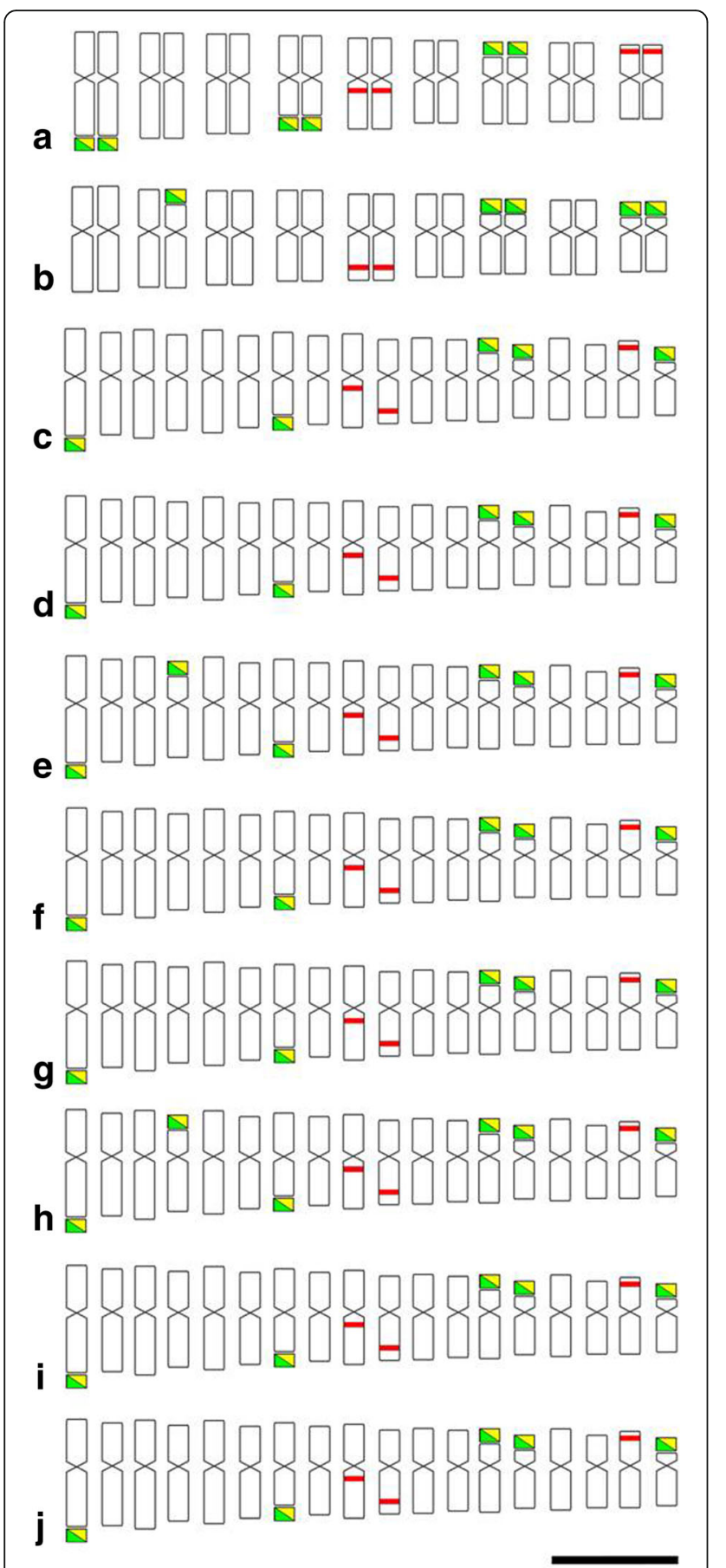

CMA $\square$ s rDNA $\quad$ 45s rDNA

Fig. 5 Ideograms showing $\mathrm{CMA}_{3}$ blocks and $5 \mathrm{~S}$ and $45 \mathrm{~S}$ rDNA sites in parents and interspecific hybrids of Passiflora HD15 progeny. a $P$. gardneri Mast., (b) P. gibertii N. E. Brown, (c) HD15-101, (d) HD15-104, (e) HD15-106, (f) HD15-107, (g) HD15-108, (h) HD15-109, (i) HD15110, (j) HD15-111. Bar $=5 \mu \mathrm{m}$

number of chromosomes [32]. The lack of karyomorphologic data for many species and generated hybrids within the genus is likely due to karyotype similarity [33]. However, we observed chromosome stability, as a constant diploid number of chromosomes was found in all hybrid germplasms investigated, as well as in the genitor species. The absence of chromosome elimination or disploidy is a positive attribute for potential breeding, as disploidy could present reproductive and fertilization issues, and species bearing this phenomenon are not recommended for use as genetic resources in breeding programs.

The detection of GC- and AT-rich heterochromatin regions can assist in hybrid characterization. $\mathrm{CMA}_{3} /$ DAPI banding was used to verify GC-rich $\left(\mathrm{CMA}_{3}{ }^{+}\right)$ and $\mathrm{AT}$-rich $\left(\mathrm{DAPI}^{+}\right)$regions. Here, $\mathrm{GC}$-rich regions were restricted to the satellites (secondary constrictions), while AT-rich regions were not directly visible (identified instead by $\mathrm{DAPI}^{-}$regions co-located with GC-rich regions. These results corroborated what has been previously described in other species of the genus Passiflora [22, 26, 34]. In our study, the absence of $\mathrm{CMA}^{+} / \mathrm{DAPI}^{-}$blocks in some hybrids was possibly due to the presence of a heteromorphic pair in the paternal parent ( $P$. gibertii). This difference in the number of satellites between $F_{1}$ hybrids could lead to chromosomal changes in $\mathrm{F}_{2}$ hybrids caused by unequal recombination during meiosis. This hypothesis could be further examined via a meiotic study or by cytological analysis of $\mathrm{F}_{2}$ hybrids using $45 \mathrm{~S}$ rDNA probes or other specific chromosomal markers.

GISH is an efficient method for hybrid identification because it allows the determination of chromosomal genomic origin even without previous knowledge of chromosome morphology $[12,16]$. It also allows the observation of recombination or alterations between different genomes [35]. In this study, GISH was successfully used to confirm hybrid status and no chromosome translocation was found. The optimization of GISH conditions allowed for the uniform labeling of all paternal-origin chromosomes and minimal cross-hybridization signal from maternal-origin chromosomes. Optimal results were obtained when blocking DNA was used at a $100 \times$ higher concentration relative to the probe. The need for such a high blocking DNA concentration suggests that both parents share many repetitive DNA sequences, which was understandable given the close taxonomic relationship between the genitor species [36]. It was thus necessary to adjust the amount of blocking DNA used in accordance with the amount of sequence DNA shared between the species used for crossing [37]. In an $F_{1}$ hybrid obtained between two species of great economic and agronomic interest ( $P$. edulis vs. $P$. cincinnata), it was not possible to identify complete chromosome subsets (nine chromosomes) specific to each parental species. Instead, three chromosome subsets were identified: eight chromosomes from $P$. edulis (completely labeled by the probe), six partially labeled chromosomes, and four unlabeled chromosomes. These results were likely due to the use of a 
low concentration of blocking DNA, since the partial hybridization of some chromosomes may have occurred because the parental species were phylogenetically related and share significant amounts of DNA sequences [38]. Conversely, an investigation of $\mathrm{F}_{1}$ and $\mathrm{RC}_{1}$ hybrids involving the species $P$. sublanceolata (Genoma-S) and P. foetida (Genoma-F) was able to identify and confirm hybrid status and visualize chromosomal recombination in $\mathrm{RC}_{1}$ hybrids and elucidation of triploidy origin in a $\mathrm{RC}_{1}$ hybrid [21]. These results demonstrate the successful occurrence of chromosomal recombination among different Passiflora species, indicating hybrid generation potential.

In this study, rDNA was demonstrated to be useful for identifying hybrid status, as well as determining chromosomal stability through analysis of the number and localization of chromosomal markers. The presence of stable karyotypes in hybrids allows useful plants to be selected and breeding programs to be advanced. Although both genitor species had metacentric and similarly sized chromosomes, chromosome-specific 45S and 5S rDNA probe-labeling provided chromosome markers with unique characteristics for each parent species, and thus allowed the reliable confirmation of hybrid status. FISH techniques using two or more repetitive DNA sequences as probes have been widely used for chromosome identification, and consequently have been able to serve as chromosome markers in certain plant species such as those of the genus Lilium L. [12]. The simultaneous use of $45 \mathrm{~S}$ and $5 \mathrm{~S}$ rDNA probes provided chromosome markers that were used for the identification of genomic material from each donor, and thereby facilitated determination of the hybrid status of Lilium [12]. In the genus Oryza L., the application of $45 \mathrm{~S}$ rDNA probes in hybrids (O. meyriana vs. O. sativa) identified two $45 \mathrm{~S}$ rDNA sites belonging to O. meyriana and one site belonging to O. sativa [39]. In Passiflora, among the nine pairs of chromosomes of each parent species, four pairs - two maternal and two paternal - could be used as markers.

The variation in the amount of $45 \mathrm{~S}$ rDNA sites in the hybrids analyzed in this study is due to the paternal genitor species presenting heteromorphic chromosome pair $2 \mathrm{~b}$, which only presents a $45 \mathrm{~S}$ rDNA site in one homolog. Thus, during meiosis this species may form gametes containing either two or three chromosomes carrying $45 \mathrm{~S}$ rDNA sites. In hybrids containing five $45 \mathrm{~S}$ rDNA sites, there was a fusion of a paternal gamete carrying two $45 \mathrm{~S}$ rDNA sites with a maternal gamete carrying three $45 \mathrm{~S}$ rDNA sites, whereas in hybrids containing six $45 \mathrm{~S}$ rDNA sites, there was a fusion of a paternal gamete carrying three $45 \mathrm{~S}$ rDNA sites with a maternal gamete carrying three $45 \mathrm{~S}$ rDNA sites. The presence of a heteromorphic homologous chromosome pair in $P$. gibertii was probably due to $45 \mathrm{~S}$ rDNA site deletion or reduction, which could not be detected using FISH on chromosomes in metaphase. Alternatively, this species presented individual differences, with some individuals carrying four $45 \mathrm{~S}$ sites and others carrying six $45 \mathrm{~S}$ sites. Crossing between these different individuals could result in individuals with five $45 \mathrm{~S}$ rDNA sites.

\section{Conclusions}

Karyotype data obtained in this study showed that the hybrids are cytologically stable. FISH demonstrated that the simultaneous use of rDNA probes provided unique chromosome markers from each parent, facilitating the recognition of each genome genitor in the hybrids, consequently confirming paternity. Similarly, GISH was successfully used for hybrid status confirmation. The application of GISH is poorly explored for the purpose of improving Passiflora species, and thus, technique optimization and the results from this study will contribute to the improvement of breeding programs involving species from this genus. Besides hybridization confirmation, GISH also allows the visualization of recombination between the homeologous chromosome and the introgression of sequences of interest.

\section{Additional file}

Additional file 1: Giemsa staining of mitotic metaphase cells from parents and interspecific hybrids of Passiflora HD15 progeny $(2 n=18)$. (A) P. gardneri Mast., (B) P. gibertii N. E. Brown, (C) HD15-101, (D) HD15-104, (E) HD15-106, (F) HD15-107, (G) HD15-108, (H) HD15-109, (I) HD15-110, (J) HD15-111. Bar $=10 \mu \mathrm{m}$. (TIFF $3954 \mathrm{~kb})$

\section{Abbreviations}

2n: Diploid number; 8-HQ: 8-hydroxyquinoline; AFLP: Amplified fragment length polymorphism; BSA: Bovine Serum Albumin; $\mathrm{CMA}_{3}$ : Chromomycin $\mathrm{A}_{3}$; DA: Distamycin A; DAPI: 4'-6-diamidino-2-phenylindole; ESTs: Expressed sequence tags; FISH: Fluorescence in situ hybridization; FITC: Fluorescein isothiocyanate; GISH: genomic in situ hybridization; $\mathrm{HCl}$ : Hydrochloric acid; PCR: Polymerase chain reaction; RAPD: Random amplified polymorphic DNA; rDNA: ribosomal DNA; RT: Room temperature; SDS: Sodium dodecyl sulfate; SSC: Salt, sodium citrate; SSR: Simple sequence repeat

\section{Acknowledgments}

The authors would like to thank UESC, CNPq and FAPESB for financial support; Coordenação de Aperfeiçoamento de Pessoal de Nível Superior (CAPES) for the scholarship granted to the first author, and CNPq for the scholarship awarded to the second author.

\section{Funding}

This research received financial support from Conselho Nacional de Desenvolvimento Científico e Tecnológico (CNPq) (Grant numeber 14/2010) and Fundação de Amparo à Pesquisa do Estado da Bahia (FAPESB) for maintaining the germplasm bank and the acquisition of reagents used in this research. The State University of Santa Cruz provided the financial support for equipments and physical structure of the Plant Breeding Laboratory where cytogenetic analyzes were performed.

\section{Availability of data and materials}

All datasets supporting the conclusions of this article are included within the article. cytogenetic studies and participated in the writing and reviewing of the final text. CAFM helped in the cytogenetic studies and the analysis of the results. 
JDU and ERFM contributed to the improvement of the FISH technique and participated in the final review of the text. All authors have read and approved the final manuscript.

\section{Authors' information}

GSS is currently a doctoral student in the Post Graduate Program in Genetics and Molecular Biology of the UESC and has experience with Passiflora cytogenetics. MMS is a full professor at UESC with expertise in genetics and plant cytogenetics. CAFM is currently a post-doctoral fellow at UESC with expertise in genetics and plant cytogenetics. JDU is a professor at CONICET - UNC and has experience in molecular genetics and plant cytogenetics. ERFM is a teacher and cytotaxonomist at UNICAMP.

\section{Ethics approval and consent to participate}

All the plant materials utilized are maintained in the Active Germplasm Bank (BAG-Passifloras), State University of Santa Cruz, managed by the corresponding author of this article. The genitor species were donated by the Brazilian Agricultural Research Corporation (Embrapa Cerrados). As stated under the methods section of this article, we obtained all the hybrid plants from BAGPassifloras.

\section{Competing interests}

The authors declare that they have no competing interests.

\section{Publisher's Note}

Springer Nature remains neutral with regard to jurisdictional claims in published maps and institutional affiliations.

\section{Author details}

'Departamento de Ciências Biológicas, Universidade Estadual de Santa Cruz (UESC), Ilhéus, BA, Brazil. ${ }^{2}$ Instituto Multidisciplinario de Biología Vegetal (IMBIV), CONICET - UNC, Córdoba, Argentina. ${ }^{3}$ Departamento de Biologia Vegetal, Instituto de Biologia, Universidade Estadual de Campinas, Campinas, SP, Brazil.

\section{Received: 2 December 2016 Accepted: 9 April 2018}

\section{Published online: 27 April 2018}

\section{References}

1. Cervi AC, Imig DC. A new species of Passiflora (Passifloraceae) from Mato Grosso do Sul, Brazil. Phytotaxa. 2013;103:46-50.

2. Bernacci LC, Cervi AC, Giovanni R, Borges RAX, Hering RLO, Serrano T, Santos-Filho LAF. Passifloraceae. In: Martinelli G, Moraes MA, editors. Livro vermelho da flora do brasil. Rio de Janeiro: Instituto de Pesquisas Jardim Botânico do Rio de Janeiro; 2013. p. 830-4.

3. Meletti LMM, Soares-Scott MD, Bernacci LC. Caracterizacão fenotípica de três seleções de maracujazeiro-roxo (Passiflora edulis Sims). Rev Bra Fruticultura. 2005;27:268-72.

4. Barbosa PR, Valvassori SS, Bordignon CL, Kappel VD, Martins MR, Gavioli EC, Quevedo J, Reginatto FH. The aqueous extracts of Passiflora alata and Passiflora edulis reduce anxietyrelated behaviors without affecting memory process in rats. J Med Food. 2008;11:282-8.

5. Vanderplank J. Passion flowers. 3rd ed. Cambridge: The MIT Press; 2000.

6. Abreu PP, Souza MM, Santos EA, Pires MV, Pires MM, Almeida AAF. Passion flower hybrids and their use in the ornamental plant market: perspectives for sustainable development with emphasis on Brazil. Euphytica. 2009;166:307-15.

7. King LA. Newly-registered cultivars to: winter 2011. Passiflora. 2011:22:16-23.

8. Santos EA, Souza MM, Abreu PP, Conceição LDHCS, Araújo IS, Viana AP, Almeida AAF, Freitas JCO. Confirmation and characterization of interspecific hybrids of Passiflora L. (Passifloraceae) for ornamental use. Euphytica. 2012; 184:389-99.

9. Oliveira RP, Novelli VM, Machado MA. Frequência de híbridos em cruzamento entre tangerina 'cravo' e laranja 'pêra'. Pesq Agropec Bras. 2005;35:1895-903.

10. Czernicka M, Msciohowaska A, Klein M, Muras P, Grzebelus E. Paternity determination of interspecific rhododendron hybrids by genomic in situ hybridization (GISH). Genome. 2010;53:277-84

11. Ran Y, Hammett KRW, Murray BG. Hybrid identification in Clivia (Amaryllidaceae) using chromosome banding and genomic in situ hybridization. Ann Bot. 2001;87:457-62.
12. Marasek A, Hasterok R, Wirjacha K, Orlikowska T. Determination by GISH and FISH of hybrid status in Lilium. Hereditas. 2004;140:1-7.

13. Ortoloni FP, Mataqueiro MF, Moro JR. Caracterização citogenética em Schlumbergera truncata (Haworth) Moran e Schlumbergera x buckley ( $T$. Moore) Tjaden (Cactaceae). Acta Bot Bras. 2007;21:361-7.

14. Zhang C, Ye L, Chen Y, Xiao J, Wu Y, Tao M, Xiao Y, Liu S. The chromosomal constitution of fish hybrid lineage revealed by $5 S$ rDNA FISH. BMC Genet. 2015;16:140.

15. Stace CA, Bailey JP. The value of genomic in situ hybridization (GISH) in plant taxonomic and evolutionary studies. In: Hollingsworth PM, Bateman RM, Gornall RJ, editors. Molecular systematics and plant evolution. 1st ed. London: CRC Press; 1999. p. 199-210.

16. Silva GS, Souza MM. Genomic in situ hybridization in plants. Genet Mol Res. 2013;3:2953-65

17. Türkösi E, Cseh A, Éva Darkó E, Molnár-Láng M. Addition of Manas barley chromosome arms to the hexaploid wheat genome. BMC Genet. 2016:17:87.

18. Junqueira KP, Faleiro FG, Junqueira NTV, Bellon G, Ramos JD, Braga MF, Souza LS. Confirmação de híbridos interespecíficos artificiais no gênero Passiflora por meio de marcadores RAPD. Rev Bra Fruticultura. 2008;30:191-6.

19. Conceicão LDHCS, Belo GO, Souza MM, Santos SF, Cerqueira-Silva CBM, Correa RX. Confirmation of cross-fertilization using molecular markers in ornamental passion flower hybrids. Genet Mol Res. 2011; 10:47-52.

20. Melo CAF, Silva GS, Souza MM. Establishment of genomic in situ hybridization (GISH) technique for analysis in interspecific hybrids of Passiflora. Genet Mol Res. 2015:14:2176-88.

21. Melo CAF, Souza MM, Silva GS. Karyotype analysis by FISH and GISH techniques on artificial backcrossed interspecific hybrids involving Passiflora sublanceolata (Killip) MacDougal (Passifloraceae). Euphytica. 2017;213:161.

22. Melo NF, Guerra M. Variability of the $5 S$ and rDNA sites in Passiflora L. with species with distinct base chromosome numbers. Ann Bot. 2003:92:309-16.

23. Cuco SM, Vieira MLC, Mondin M, Aguiar-Perecin MLR. Comparative karyotype analysis of three Passiflora L. species and cytogenetic characterization of somatic hybrids. Caryologia. 2005;58:220-8.

24. Johansen DA. Plant microtechnique. 1st ed. New York: Mc Graw Hill; 1940.

25. Guerra M, Souza MJ. Como observar cromossomos: um guia de técnica em citogenética vegetal, animal e humana.1st ed. Funpec: São Paulo; 2002.

26. Melo CAF, Souza MM, Abreu PP, Viana AJC. Karyomorphology and GC-rich heterochromatin pattener in Passiflora (Passifloraceae) wild species from Decaloba and Passiflora subgenera. Flora. 2014;11:620-31.

27. Doyle JJ, Doyle JL. Isolation of plant DNA from fresh tissue. Focus. 1990;12:13-5.

28. Jauhar PP, Peterson TS. Cytological analyses of hybrids and derivatives of hybrids between durum wheat and Thinopyrum bessarabicum, using multicolor fluorescent GISH. Plant Breed. 2006;125:19-29.

29. Gerlach WL, Bedbrook JR. Cloning and characterization of ribosomal RNA genes from wheat and barley. Nucleic Acids Res. 1979;7:1869-85.

30. Schwarzacher T, Haslop-Harrison P. Practical in situ hybridization. 1st ed. Oxford: Bios Scientific Publishers; 2000.

31. Souza MM, Urdampilleta JD, Forni-Martins ER. Improvements in cytological preparations for fluorescent in situ hybridization in Passiflora. Genet Mol Res. 2010;9:2148-55.

32. Soares-Scott MD, Meletti LM, Bernacci LC, Passos IRS. Citogenética clássica e molecular em passifloras. In: FALEIRO FG, JUNQUEIRA NTV, BRAGA MF, editors. Maracujá: Germoplasma e Melhoramento Genético. Planaltina: Embrapa Cerrados; 2005. p. 213-40.

33. Souza MM, Pereira TNS, Vieira MLC. Cytogenetic studies in some species of Passiflora L. (Passifloraceae): a review emphasizing Brazilian species. Braz Arch Biol Technol. 2008;51:247-58.

34. Viana AJC, Souza MM. Comparative cytogenetics between species Passiflora edulis and Passiflora cacaoensis. Plant Biol. 2012;14:820-7.

35. Lim KY, Matyasek R, Kovarik A, Leitch AR. Genome evolution in allotetraploid Nicotiana. Biol J Linnean Soc. 2004;82:599-606.

36. Tang F, Chen F, Chen S, Wang X, Zhao H. Molecular cytogenetic identification and relationship of the artificial intergeneric hybrid between Dendranthema indica and Crossostephium chinense by GISH. Plant Syst Evol. 2010;289:91-9. 
37. Anamthawat-Jónsson K, Schwarzacher T, Leitch AR, Bennett MD, HeslopHarrison JS. Discrimination between closely related Triticeae species using genomic DNA as a probe. Theor Appl Genet. 1990;79:721-8.

38. Coelho MSE, Bortoleti KCA, Araújo FP, Melo NF. Cytogenetic characterization of the Passiflora edulis Sims $x$ Passiflora cincinnata mast. Interspecific hybrid and its parents. Euphytica. 2016;210:93-104.

39. Xiong ZY, Tan GX, He GY, He GC, Song YC. Cytogenetic comparisons between a and $\mathrm{G}$ genomes in Oryza using genomic in situ hybridization. Cell Res. 2006;16:260-6.

Ready to submit your research? Choose BMC and benefit from:

- fast, convenient online submission

- thorough peer review by experienced researchers in your field

- rapid publication on acceptance

- support for research data, including large and complex data types

- gold Open Access which fosters wider collaboration and increased citations

- maximum visibility for your research: over $100 \mathrm{M}$ website views per year 